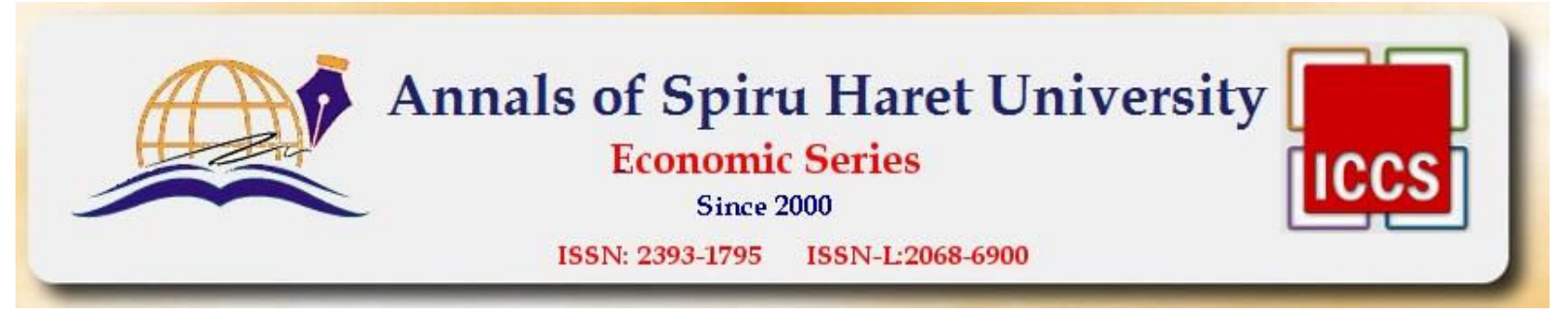

Issue 4/2016

\title{
SOCIAL PROGRESS AND ECONOMIC PROJECTS FOR DISADVANTAGED GROUPS IN ROMANIA
}

\author{
Aurelian Virgil BĂLUȚÂA ${ }^{1}$, Gabriela IOSIF ${ }^{2}$, \\ 1 "Spiru Haret" University, Faculty of Economic Sciences, Bucharest, Romania, Tel.: \\ +40.21.317.66.25, Email: baluta.aurelian@yahoo.com \\ ${ }^{2}$ INCDIE ICPE-CA, Bucharest, Romania, \\ Email: iosif_gabriela@icpe-ca.ro
}

\begin{abstract}
The paper aims to analyse the social progress, social politics, social law and successful projects applicable to some disadvantaged groups: Roma people and woman. Inclusion of Roma people is analysed from the economic point of view. The economic problems of equality by gender are presented in terms of labour rate and other relevant ratio. For Roma people, the focus of analyse is also on labour involvement.

The chapters of the communication are: introduction, literature review (state of art) in the field of social progress, theoretical background, tools for social progress in EU, economic inclusion of Roma population, economic equality by gender, conclusions.
\end{abstract}

Keywords: labour market, social progress, disadvantaged groups, economic insertion of Roma people, economic equality by gender.

JEL Classification: J4

\section{Introduction}

This communication aims to highlight the correlation between realities of the disadvantaged persons, the regulatory framework and possible solutions to real social progress in this direction. Policies focus on disadvantaged persons who can contribute to sustaining economic growth, to revitalize and promote the social inclusion of those groups by re/integration on the labour market. Policies on social progress must also pursue the increasing of the awareness of the disadvantaged persons in terms of equality and opportunities of the various projects and initiatives by encouraging their participation in the labour market.

EU has general instruments for social progress and special tools for disadvantaged groups. We selected two disadvantaged groups: Roma people and woman. In the paper we put together principles, law applicable, realities and perspectives, projects done and projects to be done. The analysis of social progress for Roma people and woman is based on statistical information and possibilities of EU programs.

The successful projects of the EU programming period 2007-2013 and the experience gained may be valorised in the new programming period to improve the situation of disadvantaged groups. At the same time, new theoretical contribution on project management and procedures of applicants or public authorities will help the economic and social performance of EU funds.

\section{Literature review in the field of social progress}

In Romania the problems of social progress with focus on disadvantaged groups is more and more subject of research. The concepts for social development are already integrated and systematized (Zamfir \& Stanescu, 2007).

The economics has already definitions for social cost, social security, social welfare, social benefits, social-welfare function. A social-welfare function is used to determine the relationship between overall welfare, and the welfare of different citizens [Bannock, et all, 2003]. The problem of work for all started to be very important after the World War II and increased in importance. Mass unemployment is not just economically wasted but also socially disastrous. When unemployment 


\section{Annals of Spiru Haret University \\ Economic Series \\ Since 2000}

ISSN: 2393-1795 ISSN-L:2068-6900

\section{Issue 4/2016}

rises, all kinds of social tensions increase [Freeman \& Soete, 1994]. In Germany, the recent theory accepted that "social work can be seen as a specific method of communication which has the aim to identify the reasons for necessary and legitimate help" [Boomes \& Scherr, 2000, from Klassen, 2011]. In our days, social work and social action has to identify the problems of social values generally accepted, to make them public, to propose new law and to advocate for social change.

The experience of projects from programming period 2007-2013 in the field of management started to be disseminated by communications or by books. The new model, "managerialism", different from the traditional bureaucratic approach, is focus on problem solving, explicit implementation of performance criteria and measurement, attention to internal control, enhanced discipline and control in resource utilization [Cioclea, 2011].

In the economic research the problem of EU funds access is more and more important. The main constraints identified are: long period of evaluation projects during the competition, long period to signing the contracts between applicants and public authorities for management EU funds, very long term for payment eligible expenses of the projects, communication between public authorities and applicants [Cosea, 2013].

The social economy has developed quickly in the last years. It has exceeded stage concepts. Now the economic and social science may do progress to evaluate the stages of social economy, to identify functional principles, like solidarity and the participation of the members, organization types of the economical entities [Netedu Adrian, 2013].

The equality by gender passes from theoretical approach and social understanding to economic tools to prevent or to improve the situation of woman. EU law for equal treatment by gender is in force in all Member States. In accordance with EU law, the Governments draw up programs that have already at least one generation, including the experience for project management and implementing.

Roma population was already identified as an EU problem. In the pre-accession period, Romania started, some local project to identify the Roma situation and to project tools for action. The new step is a national strategy for Roma population and integration of social, health and economic instruments to improve the situation.

\section{Theoretical background}

The paper uses statistic information collected by National Institute of Statistics, in accordance with EU statistic procedures.

In the paper we use the experience acquired in projects financed by EU. It is the generalisation and dissemination of social progress in special cases.

\section{Tools of social progress in $\mathrm{EU}$}

Most of the recent economic research is seeking solutions that will enable the European Union to emerge from the new phase of the economic and financial crisis triggered in 2008, to recover and to turn its economy towards smart, sustainable and inclusive growth, accompanied by high levels of employment, productivity and social cohesion. For these objectives the European Commission approved "Europe 2020 Strategy". This growth strategy for the next decade represents a coherent framework for the Union to mobilize all its instruments and policies and Member States are allowed to take coordinated and consolidated actions that combine financial support, facilitating the access to the labour market, health and social services. In this strategy we want to highlight one side approached, the economic component of the intervention for disadvantaged groups. Is accepted that „Inequalities are numerous and diversified" [Negroponti-Delivanis, 2010].

Even during the last crisis, a central objective of the Romanian Government on social inclusion is the continuation of efforts to develop an inclusive society by providing services for integrated social 


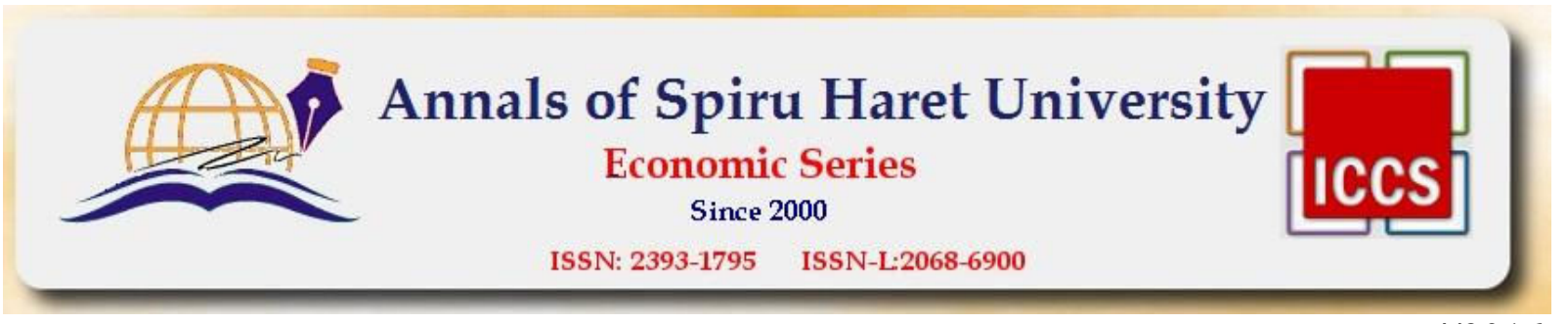

Issue 4/2016

inclusion, based on a real assessment of the individual needs, by developing the tertiary sector and by ensuring equal opportunities for all, with special emphasis on vulnerable groups. [National Strategic Report, 2008-2010]. In the terms of our days, we have to conclude that a nation is composed of members. All the members of a nation may succeed or may fail [Reich B. Robert, 1996].

Implementation of projects for development of human resources has contributed and continue to contribute to a better visibility of the social economy, representing favourable conditions for crystallization of a national strategy to promote the domain in accordance with the recommendations addressed to Member States and with the recognition of the contribution, which it has in economy and in employment issues.

To actively promote the participation of vulnerable people in the community, it is necessary not only to meet the needs of training and integration into the labour market, but also to support them in overcoming the special needs of their status as disadvantaged group, such as those related to combat stereotypes, through information and awareness about the potential and the existent opportunities.

The social economy is based on the idea that people in difficulty, marginalized or excluded, which are seen as a problem for society, can be a resource for society, becoming from assisted or excluded actors, citizens with rights and obligations, taxpayers.

We cannot speak of sustainable development of society without consideing the economic and social development, high levels of employment, vocational training opportunities as a result of acquiring new skills, in order to raise the standard of living. Sustainable development means economic development, balanced and equitable, high levels of employment, social cohesion and inclusion. Increasing the competitiveness of vulnerable people, to support the development of human capital, should be an essential condition for ensuring increased opportunities to integrate into a modern and flexible labour market. Also, this will lead to a balanced economic development, because there will be trained and competent people in the labour market, who are trained in professional advancement. Sustainable development can be simply defined as a better quality of life for everyone, both for now and for future generations.

Developing competencies, knowledge and skills, in line with labour market needs, exchange of experience, represent ways that can ensure sustainable development and a dynamic of labour market.

A change of mentality is required, both in terms of setting up innovative forms of social economy, and for increasing awareness. It is needed to combine the individual responsibility with the collective one, for economic and social development of society and to increase the level of motivation for broadening knowledge and skills development of vulnerable persons.

The European strategy for smart, sustainable and inclusive growth - Europe 2020 promotes: empowering people through high levels of employment, investing in skills, fighting poverty and modernizing labour markets and training systems and social protection, in order to help people to anticipate and manage change and to build a cohesive society.

Inclusive growth requires ensuring for all citizens access and opportunities throughout life. This consideration is supported by several documents.

\section{Economic inclusion of Roma population}

At EU level, the Roma minority, the most numerous through the 10-12 million Roma in Europe, is a priority vulnerable group in social and economic inclusion aspects. Despite the multitude and intense European actions to promote social inclusion in the last two decades, Roma minority still has a problematic situation and faces the phenomenon of the lack of prospects. It is manifested by the decreased access to education and training, mismatch between the qualifications held and the demands of the labour market, lack of the support services for people who want to initiate a business, lack of initiative and desire for involvement. The Improvement Strategy of Roma 2011-2020 provides, as a 


\section{Annals of Spiru Haret University \\ Economic Series \\ Since 2000}

ISSN: 2393-1795 ISSN-L:2068-6900

\section{Issue 4/2016}

priority direction, increased efficiency active measures for Roma inclusion on the labour market and regulation and promotion of active measures for guaranteed minimum income beneficiaries, by facilitating access to retraining courses.

Compared with the situation in Europe, the Roma in Romania have been recording a low participation in the labour market, but have a proactive insertion behaviour, resorting to informal integration opportunities. Employment of Roma is characterized by a very low participation in the formal labour market, but with high participation in informal labour market, without social security mechanisms.

Roma women have quite a disadvantaged situation, they represent less than one third of the total Roma population employed. According to data provided by the Romanian Government, the number of housewives is four times higher than the national average. Nearly half (48\%) of Roma women were housewives, they have never worked (Romanian Government Strategy, 2011-2020).

The European Platform for Roma Inclusion, launched in April 2009, was conceived as a framework for enhanced cooperation, on a voluntary basis, among relevant stakeholders to this issue, namely between Member States, European institutions and representatives of Roma, in order to exchange best practices in social inclusion area. The 10 common basic principles for Roma inclusion are: constructive policies, pragmatic and non-discriminatory, targeting clear, but not exclusive, intercultural approach, the integration objective in the traditional society, awareness of gender, policy transfer based on experience, using the Community instruments, involvement of local and regional authorities, civil society involvement, active participation of Roma [Cosea, 2013]

In the same strategy, Roma women appear explicitly as a vulnerable group in projects from the list with specific actions undertaken by the National Agency for Equal Opportunities - ANES. [Făiniş \& Andronie, 2012]. The principles that must govern the social economy are: to respect the rights of all citizens, equal opportunities for all, awareness the complexity of various problems and situations faced by vulnerable groups in the Romanian society, taking into account the local context, adopting an approach that has in centre the need, supporting solidarity between generations in order to stop the "contagion risk of poverty from one generation to another", supporting intra-regional solidarity and permanent consultation.

In the conditions of an increasing and mechanized economy, trades that are based on work by hand have lost popularity and, despite the fact that the handicraft is an essential part of their identity, Roma people tend to abandon it, because it does not bring income as before. Therefore, creation of innovative employment and flexible forms for Roma people and women in risk condition, by setting up structures in the social economy, supports the exploitation of the local workforce, increasing the employment opportunities for people at risk of social exclusion. The structures of social economy can be a tool to ensure workers' the ability to acquire, to maintain and increase their value in the labour market. Social entities contribute to strengthening entrepreneurship, integrate social responsibility and promote active social integration of vulnerable groups.

These structures may take the form of social enterprises. They need support for the essential role performed as a catalyst for social innovation. Also, must consider the huge potential of social enterprise in relation to the improved access to a job and working conditions for women and young people in particular, but also for various categories of disadvantaged workers [National Strategic Report on Social Protection and Social Inclusion, 2008-2010].

\section{Economic equality by gender}

Inequalities by gender are generated in time by natural, social and educational factors. The focus long time of human activities on physical power and the production with labour intensity in pre- 
industrial period represented the natural and social factors of inequalities by gender. In post-industrial period such inequalities are not justified [Grosu, 2008].

Inequalities by gender represent at the same time an economic problem. The differences of income (namely salaries) and ratio in entrepreneurship are economic involvement. Previous studies proved that segregation by gender involves discrimination in the field of salaries. The situation is complex because "is not only one factor that generates segregation and economic disparities by gender" [Făinişi \&Andronie, 2012].

Also at EU level, women are implicitly defined as a vulnerable group, their situation representing a priority in most areas of regulation and action.

In official documents in Romania, woman appears in a situation of vulnerability, especially in relation to the issue of violence and employment opportunities in the labour market. The official documents of Romania's social problems did not hide the unfavourable aspects. It is accepted that the "risk of social exclusion manifests stronger among women than men in all stages of life, as a reflection of their low participation in the labour market. The risk of poverty is especially higher among elderly women and single parents with dependent children, the predominant group of them being represented by women" [National Development Plan, 2005].

Also, an important goal was "to facilitate the insertion into the labour market of women who are in situation or risk marginalization" being mentioned in particularly the communities of Roma women, older women and women with no education. [National strategy for equality between women and men, 2010-2012].

The fact that unemployment is quite high in the region and that many work as day labourers in agriculture must urge the local government to find solutions. A high unemployment is a problem that largely affects the local economy and quality of life. Economics and economic growth theory say that "regional human capital is the basis of multiple regional or community differentiations" [Basaraba, 2006].

In every kind of strategy for equality between women and men, an important goal is to facilitate insertion in the labour market of women, reducing gender pay gap and implementing measures to reconcile the family life with the professional one.

In the period of EU programming 2007-2013, with deadline December 2015 for Romania, a lot of projects succeed to change and to improve the situation of women. Spiru Haret University has implemented projects such as ProFeminAntrep (www.profeminantrep.ro) and ProFemin (www.profemin.ro). The central idea was to have special projects for women and to increase the situation of women by education for the labour market or for entrepreneurship.

National Institute for Research \& Development in Electrical Engineering developed projects for innovation and organised competition by equal chances of success on gender. The projects like "Profis", or "Clean Access in Calarasi-Silistra Cross Border" follow-up this idea to help women to higher standards than average. The importance and details of the projects, to be used by new project managers or by new staff in EU projects, are presented on the special sites of the projects or on the site of the institution, www.icpe-ca.ro.

The results and the procedures of successful projects from previous programming period may be valorised in the new programming period only they will be preserved in the new guidelines outline.

\section{Conclusions}

Because inequalities are numerous and diversified, EU and Member States have to mobilize all its instruments and policies, to take coordinated and consolidated actions that combines financial support, facilitating the access to the labour market, health and social services, with focus on intervention for disadvantaged groups. 


\section{Annals of Spiru Haret University \\ Economic Series \\ Since 2000}

ISSN: 2393-1795 ISSN-L:2068-6900

Issue 4/2016

Employment of Roma is characterized by a very low participation in the formal labour market, but with high participation in informal labour market, without social security mechanisms.

In every kind of strategy for equality between women and men, an important goal is to facilitate insertion in the labour market of women, reducing gender pay gap and implementing measures to reconcile the family life with the professional one.

The results and the procedures of the successful projects from previous programming period may be valorised in the new programming period only they will be preserved in the new guidelines outline.

\section{References}

1. Basaraba, Adrian, "Human Resources - an Essential Factor for Regional Development. Case Study: V West Development Region" in Globalism, Globality, Globalisation,. Ten Years of European Studies in Cluj, (Cluj-Napoca: Presa Universitara Clujeana, 2006), p. 65.

2. Bannock, Graham; Boxter, R.E.; Davis, Evan, The Penguin Dictionary of Economics (Seventh edition, London Penguin Books, 2003), pp. 359-360.

3. Boomes, M. \& Scherr, A., Soziologie der Sozialen Arbeit, Eine Einfuhrung in Formen und Funktionen organisierter Hilfe (Weinheim, Juventa, 2000).

4. Buzducea, Doru, "Social Work in the New Millennium: A Global Perspective", in International Social Work, A Supplement of Social Work Review (Bucharest: University of Bucharest Publishing House, 2011), p. 21.

5. Ciceo, Georgiana, "The Relevance of the Theories of European Integration for Explaining the Process of European Union Enlargement", in Globalism, Globality, Globalisation, Ten Years of European Studies in Cluj (Cluj-Napoca: Presa Universitara Clujeana, 2006), p. 139.

6. Cioclea, Alexandra Ema, "Performance Evaluation Initiatives in Public Organizations", in Institutions and Economic Performance (Publishing House of University Alexandru Ioan Cuza, Iaşi, 2011), p. 81.

7. The Committee on Employment and Social Affairs, Report on social entrepreneurship and social innovation to combat unemployment, $\mathrm{http}$ ://www.europarl.europa.eu/sides/getDoc.do?pubRef=//EP//text+report+A8-2015-0247+0+DOC+XML+V0//RO

8. Cosea, Mircea, Our Crisis of All Days (Bucharest: ProUniversitaria, 2013), p. 159.

9. Freeman, Chris \& Soete, Luc, Work for All or Mass Unemployment (London: Printer Publishers, 1994), p. 9.

10. Făinişi, Florin \& Andronie, Maria (coordinators), Study on Gender Segregation in the Labor Market (Bucharest: Editura Fundaţiei România de Mâine, 2012), p. 38.

11. Government of Romania, National Strategic Report on Social Protection and Social Inclusion 2008-2010, http://www.mmuncii.ro/pub/imagemanager-/images/file/Domenii/Incluziune\%20si\%20asistenta\%20sociala/Raportari\%20si\%20indicatori/170609Raportul\%202008\%20-

$\% 202010 \% 20$ Final\%20octombrie\%-202008_doc.pdf.

12. Government of Romania, Romanian Government's Strategy for Inclusion of Romanian Citizens Belonging to the Roma Minority for the Period 2014-2020, http://www.anr.gov.ro/docs/Site2014/Strategie/Strategie_final_18-11-2014.pdf, p. 5

13. Grosu, Nicolae, The Quintessence of Sociology (Cluj-Napoca: Dacia, 2008), pp. 107-108.

14. Klassen, Michael, "Systemic Perspectives on Social Work", in International Social Work (2011), p. 31.

15. Negroponti-Delivanis, Maria, The Neoliberalisme and the Deep Cause of the Actual Crises (Târgovişte: The Books of CEMIMES, vol. 4, no. 1, 2010), p. 15.

16. Netedu, Adrian, "From Social Economy to Solidarity Economy. Specific Similarities and Differences", in Journal of Social Economy, no. 3/2013 (Bucharest: Hamangiu, 2013), p. 14. 


\section{Annals of Spiru Haret University Economic Series \\ Since 2000 \\ ISSN: 2393-1795 ISSN-L:2068-6900}

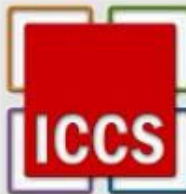

Issue 4/2016

17. Project "Clean Acces in Calarasi-Silistra Cross-Border Area", on http://www.icpeca.ro/proiecte/proiecte-europene/cleea.pdf

18. Project "Profis-Promoting Finance for Innovation in South-East Europe" on http://www.icpe-ca.ro/proiecte/proiecte-europene/profis.pdf

19. Project "ProFeminAntrep" financed by Social European Fund, on www.profeminantrep.ro.

20. Project "ProFemin" financed by Social European Fund, on www.profemin.ro.

21. Barrett, Ruth, "Disadvantaged groups in the labour market", Economic \& Labour Market
Review,
vol.
4 ,
No.
6 ,
June
2010,
on

file://C:/Documents\%20and\%20Settings/Admin/My\%20Documents/Downloads/ELMR-Jun10-

Barrett_tcm77-101642.pdf

22. Reich B., Robert, The Work of Nations. Preparing Ourselves for $21^{\text {st }}$ Century Capitalism (Bucharest: Paideia, 1996), p. 19.

23. Zamfir, Cătălin \& Stănescu, Simona (coordinators), Encyclopedia of Social Development (Bucharest: Polirom, 2007), p. 27. 
